\title{
The World Reeling from a Global Pandemic: COVID -19 and Its Social and Psychological Repercussions
}

\author{
Maysa Abdel Aal Ibrahim, Ph.D. \\ Department of English Language and Literature \\ Tanta University, Egypt \\ maysa.ibrahim@gmail.com
}

\begin{abstract}
The COVID-19 pandemic which has violently attacked the world this year has been more than a national and a global health threat owing to the multidimensional aspect of its impact. The pandemic has caused a collective trauma to the human race because its psychological residues are far reaching; it has infiltrated through layers of almost every aspect of life and in all of them has deeply affected human psychology and relationships. The social-distancing measures the pandemic has mandated and the fear of infection it has struck in humans have created distances between individuals. The aim of this paper is to reveal the impact of the pandemic on the psychology of humans and on their relationships. The paper examines those two issues through an exposition of several pandemic-related psychosocial stressors and aspects of life impacted and altered by the pandemic, such as education and the use of technology at work and in social life.
\end{abstract}

Key words: COVID -19 , lockdown, social distancing, economic recession, infection, fear, stress, anxiety and depression.

\section{Introduction}

The COVID-19 pandemic which has swept the globe this year has put the entire human race in the same predicament. Although people have suffered in varying degrees, this predicament has reminded us that we, humans, belong to one another; our ordeals, our trials and tribulations and our welfare are those of the whole species. In fact, COVID-19, with its indiscriminate harassment to the 
human world has acted as a reminder to the human race that the lives and fates of humans are bound up together in an infinite string from creation to eternity.

The pandemic has shaken man's belief in his power. A little infectious bug has disturbed the whole earth, disrupted systems and habitual modes of life long taken for granted, disrupted life itself. Man stands powerless. The virus has killed almost two million people in the world, infected millions and struck fear in the rest of humanity. It has put economies, education, and every aspect of life in a state of paralysis and has caused stress, anxiety and depression to people across countries. A virus has changed concepts of psychology and imbued fear with new meanings. Fear of another is well known to humans; however, the pandemic has introduced to human psychology a new type of fear: fear of another and of oneself for the same other.

As people were falling sick, getting hospitalized, dying or surviving, others had to keep the wheels of life going. In order to do so, they resorted to man's colossal achievement in life: technology. The use of technology in the work from home policy, in online education, social gatherings and events has eased the state of paralysis that otherwise would have taken hold of man's life during the pandemic. However, if technology has been able to put us in a makebelieve story that life could still go on during the pandemic-work, education, and even weddings could be done from home- unfortunately, it does not have the power to alleviate human misery, the grief over lost ones, the financial hardships humans have gone through, the social isolation and loss of human support, all of which are stressors the pandemic has brought in its wake and all of which have left deep imprints on man's psychology and relationships.

The COVID-19 pandemic has impacted human psychology in radical ways; it has left man not only with feelings of powerlessness, but also with feelings of loneliness and separation. The pandemic has shed bleakness on the world with all the pain it has caused humans. If man's psychology has been severely injured by the pandemic, his relationships have been more so. The social isolation the pandemic has mandated on man is a major part of his trials and tribulations. This paper tackles the COVID-19- induced psychosocial stressors, such as health and financial adversities, social isolation and home confinement, as well as aspects of life affected by the pandemic, such as education and technology. In all of those issues, my primary goal is to delve 
into human psychology and relationships and to attempt to explore the change the pandemic has brought to them, and the direction in which they are moving.

\section{Analysis}

According to American research scientist, Edwin D. Kilbourne, a pandemic is an outbreak of a disease that usually spreads throughout the globe, afflicting millions of people across countries. A virus causes a pandemic when most people do not have a "preexisting immunity" to it, hence transmits easily from a person to another causing severe illness (Kilbourne 1977, 1227). Kilbourne points out that for a virus to spread widely it should also have an inherent capacity for transmission among humans. In his own words, "Although it seems clear that deficiency of antibodies in the human population is the cardinal requirement for pandemic spread of an influenza strain, the virus also must possess an intrinsic capacity to spread from person to person" (Kilbourne 1977, 1227).

The aforementioned words are a medical definition of a pandemic. However, a pandemic does not only cause sickness and present humanity with a health threat but also causes sufferings and a number of psychosocial stressors (Taylor 2019, 26). Similar to previous pandemics, COVID-19 has caused financial adversities, social isolation due to enforced social distancing measures, confusion of routine and collapse of healthcare systems due to overcrowding of hospitals. All of the aforementioned byproducts of COVID-19 have resulted in a human collective trauma featured by psychological morbidities among the infected and non-infected communities alike. Stress, fear, anxiety, insomnia, loneliness and depression are some of the psychological sequelae of the COVID-19 pandemic.

The foremost psychosocial stressor the pandemic has induced is the sickness it has inflicted on many people and the health threat it has presented for many others. Health care systems in most countries were not ready for such a lethal foe as the COVID-19 pandemic. In Italy, for instance, the pandemic fuelled catastrophic repercussions with respect to hospitalizations and deaths. The influx of the massive number of patients with COVID-19 into hospitals, which exceeded by far the capacities of the Italian medical healthcare system, including healthcare staff, intensive care units, as well as equipment such as 
ventilators, became a grave psychosocial stressor, both to individuals and to the Italian national healthcare system. Between March and April, 2020, intensive care units in the region of Lombardy - the region hit the hardest by the pandemic, and home to a sixth of the Italian population of ten million inhabitants - treated almost ten times more patients than usual (Usuelli 2020, 86-87). Mortality rates were extremely high in the region, where they reached 10,043 deaths by March 2020 (Indolfi and Spaccarotella 2020, 1415), and 21,157 in the whole of Italy, a number which amounts to the total deaths in six European countries-Spain, France, Germany, UK, Switzerland and the Netherlands - by the same date (WHO 2020).

Healthcare workers and doctors in Lombardy were frontline victims of the COVID-19 tragedy; they paid a huge price in order to cope with the number of patients they tended to. Due to lack of personal protective equipment (PPE) and training in the proper use of PPE, 11,000 health workers were infected, and 100 died in March 2020 (Indolfi and Spaccarotella 2020, 1415). The reason for the Italian national health crisis - described as "the most serious event in Italian history after World War II"- is said to be that Italy, the first country in Europe affected by the Coronavirus, was "caught unprepared" for the disease and that it also initially underestimated its gravity, leading to a sluggishness in compliance with mandated health measures and containment of the virus (Indolfi and Spaccarotella 2020, 1414).

Another major psychosocial stressor the COVID-19 pandemic has induced is the economic recession the world has gone through, hence the financial hardships individuals, companies and businesses have suffered since the outbreak of the pandemic. In the words of economist Kalim Siddiqui, COVID-19 "has triggered the sharpest and deepest contraction of GDP (Gross Domestic Product) in the history of capitalism as globalization has gone into reverse" $(2020,25)$. Siddiqui asserts that 102 countries have approached the International Monetary Fund (IMF) for financial support so that they can cope with the pandemic-related recession $(2020,31)$.

The pandemic has hit many sectors, particularly private sectors, the sector of tourism, travel and entertainment, multinational enterprises (MNEs) worldwide, as well as workers and self-employed individuals, leading to bankruptcy and closure of many firms and factories, huge layoffs of workers 
and a tremendous increase in unemployment rate. Economists predicted that the sudden stop in mobility and dealings could strike an even bigger blow to the global economy than the Terrorist attack of September 2011 (Semuels 2020, $38)$.

During the peak of the pandemic, as people would venture outside their homes only to buy extreme necessities - mostly food - countries worldwide have experienced a significant contraction in economic activity. By the first half of the year, the member states of the European Union witnessed a 22\% drop in their economic activity, and the US a 14\% decline. Many businesses, such as restaurants, bars and coffee shops were required to shut down; others had no "cash cushion" (Semuels 2020, 38). Studies reveal that by the second week of March, the revenues of some restaurants in the US had dropped by $85 \%$ and those of theaters by $95 \%$. Companies and firms also underwent severe distresses. Goldman Sachs Group asserted "a historic economic contraction" and a job loss of 20 million people by July 2020, pushing the national unemployment rate into staggering figures. By the end of March 2020, 6.6 million Americans filed unemployment claims (Shawn, Joe, Reade, and Naughton 2020).

Those are only some of the adversities the pandemic has inflicted on the global economy. At the human level, they ring a bell of poverty and starvation, of lack of resources and bare survival. Workers around the world, particularly hourly workers who get paid only when they show up to work, have been severely hit by the pandemic. Self-employed individuals have equally suffered severe financial adversities. During the lockdown, and when it was later eased, people were not willing to risk their lives in order to carry out the regular life activities they used to be engaged in, such as having a haircut, exercising with a coach, going on an errand in a cab, checking a bad tooth at a dentist's, or even asking a regular home cleaner to come, to name only a few of the normal everyday life activities in the lives of some. Everything could wait for fear of contracting the virus, as long as all maladies were not related to COVID-19. Hence self-employed individuals who used to render those services to others were not in demand, a condition which profoundly injured their livelihoods. Those individuals did not only suffer the stress, panic and anxiety of contracting 
the virus or infecting another, but also the fear, and often the reality, of not being able to provide for themselves and their families.

If developed countries and individuals with high income can recover from those economic recessions and emerge out of the pandemic unscathed, developing countries and low-income individuals will certainly be severely hurt. It is estimated that $55 \%$ of the people worldwide have no adequate social protection, therefore have no basic food security and nutrition (United Nations Development Program UNDP 2020), a reality that can only be exacerbated by a global pandemic such as COVID-19. A study conducted on the financial crisis induced by COVID-19 in four African countries, Nigeria, Uganda, Malawi, and Ethiopia, asserts that $55 \%$ of households in Nigeria had to reduce their food consumption in order to cope with the economic shock. In Uganda, $43 \%$ of the population tapped into their savings, and others borrowed money or asked for financial support from family and friends (Weber, Palacios-Lopez, and Contreras-Gonzalez 2020). The economic repercussions of COVID-19 on lowincome countries are yet to be felt. World Bank studies show that COVID-19 could push 40 to 60 million people globally into extreme poverty, 27 million of whom live in Sub-Saharan Africa (World Bank 2020).

Those financial hardships experienced by many people around the world have aggravated the psychological stresses already induced by COVID-19. Studies reveal that the pandemic-related economic recessions have had a significant adverse effect on people's psychological and mental health, causing stress, anxiety and depression to many, at times pushing individuals into suicide. Researchers argue that suicide rates have increased particularly in developing countries where people are experiencing more severe crises than in developed countries and where the fragility of the mental health of some individuals play a role in driving them to extreme depression (Griffiths and Mamun 2020, 1). Although this is very true, the suicide of the finance minister of Germany's Hesse state, Thomas Schaefer, who was overwhelmed with worries over how to cope with the economic recession (EURACTIV 2020), proves that humans' mental endurance and suicidal thoughts may at times be a personal issue, rather than one related to creed or class. However, it remains true that economically disadvantaged people are more vulnerable, and therefore more prone to mental impairment, depression and suicidal thoughts, a fact 
which explains the increase of suicide rates during the recession in countries such as India, Bangaladesh and Pakistan. In Pakistan, 16 cases of suicide out of a total of 29 , occurring since January 2020, are related to the economic recession (Mamun and Ullah $\mathrm{m} 2020,4)$. Suicide pacts have also taken place in India, Bangaladesh and other countries. A young couple in Bangaladesh committed suicide in March 2020 due to poverty; the couple hung themselves in their home, leaving behind a 3-year old child (Griffiths and Mamun 2020, 2). The pandemic has had grave psychological repercussions, particularly for those with lowest incomes and least resources, some of whom were driven to the extreme limits of depression and suicide.

Sickness and economic recession are not the only stressors related to the pandemic; social isolation has proven to be as detrimental for many people around the world. Connecting with others is an inherent need in man; consequently, there is a marked relation between social connectedness and physical and mental health. Researchers assert that cultivating successful, enduring relationships is an invigorating process both physically and psychologically; they argue that developing successful relationships helps "boost self-esteem, sense of belonging, and reassurance as to one's social desirability" (Cornwell and Laumann 2013, 4-5). On the other hand, research has proven that social isolation and loneliness lead to adverse health consequences, including depression, poor sleep quality, poor cardiovascular function, cognitive decline and dementia in elders (Hawkley and Capitanio 2015, 3). In the words of Hawkley and Capitanio, intense feelings of loneliness are "the toxic players in persistent psychosocial problems and the slowly unfolding and unremitting physiological changes that can lead to clinical disease, disabilities and mortality" (Hawkley and Capitanio 2015, 2).

The Coronavirus has landed on this very busy planet to change its features, as it were, to bring everything to a halt. The enforcement of lockdown, curfews, social distancing measures, which entailed the closure of schools, colleges, shops and entertainment places, all those measures have changed the face of the earth, infringed on personal freedoms, and resulted in man's abandonment of his habitual mode of life. The bustle and hustle of cities surging with commerce, businesses and the challenges of technology, a mode which had given the new millennium its dominant character, has faded away and has not 
come back even when those measures were eased. Paris, a city that used to glow with romance, has turned, during the lockdown, into an open prison, with deserted streets that were reminiscent of "the 1940 exodus from [the city] when the German army closed in" (Hussey 2020, 41). A few months later, Paris in October 2020 is still not the city of the past; the decline in the number of people who visit cafes, restaurants and tourist attractions - a whopping $40 \%$ declinehas left Paris with a wholly different vibe. World cities, such as London, New York and San Francisco, have turned from "peak cities to ghost towns" (Stevens 2020). As much as streets and places are deserted, people are "confined to their homes in densely packed neighborhoods" (Stevens 2020).

Home confinement has presented a dramatic change of lifestyle to humans. It has meant loss of social connectedness, and also of a whole world outside that used to offer engaging activities, such as eating out with friends, shopping, going to the movies or the theater, doing physical exercise, and many other countless activities. This new mode of life mandated by the pandemic, though tolerated by some, has been distressing for many people. A plethora of studies conducted in different parts of the world reveal that depression, stress and anxiety were outcomes of engaging in social distancing behavior during COVID-19. For example, participants examined for depressive symptoms in February and March 2020 by the center for epidemiological studies depression scale recorded that they suffered loneliness and often had "crying spells;" others recorded symptoms of anxiety and expressed feelings of "not being able to stop or control worrying," of being "nervous, anxious, or on edge" most of the time (Marroquin, Vine and Morgan 2020, 3).

Those emotions of anxiety and fear presently expressed by many individuals worldwide have been triggered by the pandemic which is acting like a colossal wave sweeping humanity on its way. Nonetheless, under this wave, as much as some people are experiencing anxiety and fear of different things - of death, disease and loss, to say the least - there are others who are experiencing calm and serenity. According to theories of fear and anxiety, individual variations among humans with respect to their responses towards threats and stressors are attributed to their biological and psychological constitutions (Jacofsky et al). Although fear and anxiety are both universal human, as well as animal, emotions, psychoanalysts and behaviorists affirm that those two 
emotions have genetic biological and psychological components. Babies who are born with biological, genetic brain imbalances, specifically in the limbic section where the amygdala - which is responsible for the individual's emotional system - exists, are more sensitive to stimulation and stress than other babies (Jacofsky et al). They grow up with extra-sensitive temperaments, and are therefore at a higher risk for developing anxiety disorders. According to American psychologist and researcher, Edmund Bourne, who believes that fear and anxiety are brought about by various causes operating on numerous different levels, genetic dispositions in the brain are not the sole factors responsible for causing fear and anxiety; parental upbringing of a child is equally important. Inadequate parenting, whether due to neglect, abandonment or abuse, results in a profound sense of insecurity and shame that causes anxiety disorders and elevates an individual's sense of fear towards threats (Bourne, 42). In other words, early experiences can contribute to a psychological vulnerability, which partly explains why some people are more prone to experience anxiety than others are. Both biological and psychological predispositions are regarded as long-term causes of fear and anxiety, triggered by short term stressors such as significant personal loss or life change (Bourne, 42).

Along with heredity and upbringing, a person's belief system, which is his perception of him/herself and of the world - which I presume is also a result of childhood experiences and upbringing - is largely responsible for the levels of fear and anxiety with which he/she responds to stressors (Jacofsky et al.).The individual's belief system influences his/her appraisal of him/herself and of the stressful event or situation he/she is facing and therefore determines his /her perceived ability to cope with it. What matters is not the ability to cope with or to control the situation, rather the perception of the degree of control a person has of him/herself (Jacofsky et al.). Fear and anxiety are triggered when a person's belief system results in an overestimation of the threat and an underestimation of his/her ability to cope with it (Jacofsky et al.). It is the gap between the two which triggers an individual's anxiety. Therefore, those individuals who are unable to cope with the stresses of the pandemic are those who suffer biological and psychological vulnerabilities and whose belief systems and perceived control do not provide a positive outlook on their abilities to be in control in face of threats. 
An ironic aspect of the current COVID-19 situation is that in the remedy part of the problem lies. The interventions most essential for pandemics, the social measures enacted for the containment of the virus disrupt by necessity social life and the social processes that support individuals and help them cope with stress during hard times. If social connectedness is fundamental to the individual's happiness and mental wellbeing, as afore-mentioned, the need for it is even more poignant in difficult times. According to scientific research, social support "helps individuals maintain a sense of control and mastery as well as access to coping resources during periods of strain," and, therefore, "network loss can reduce sense of control and decrease a person's ability to cope with stress" (Cornwell and Laumann 2013, 3).

However, at the other end of the spectrum, individuals whose emotional stability support them in the face of threats and stressors and also those who find inner peace in solitude, therefore can adapt to staying at home for long hours without being inflicted by loneliness, have not suffered as much the harshness of social isolation. In fact, some individuals have discerned hidden benefits in COVID-19; the new mode of life has meant for them relief from the stresses of the outside world, simplicity of routine, connecting with family, doing the human things they missed in the quick-paced, pre-pandemic life. The lockdown has therefore not entailed for them loneliness and misery, as it has for many others, rather a slower pace of life, less work, more bonding with kin and family, and more time for contemplation. The lockdown has compensated the shortcomings of modern life under the umbrella of a sophisticated technology, one which encapsulates the globe with a mentality of racing with time, a material-oriented mentality that favors the pursuit of earthly luxuries over the nurturing of the soul. Alosious, a poet from India, celebrates the fact that "nature returns to form" in the lockdown. In her poem, "Locked down...happiness?" she resents the quick-paced pre-pandemic modern life, a life empty of love and meaning:

Rushing and running,

Becomes the order of life.

No time to stop and smile-

At a friend,

Or know a stranger, 
Or, take time to analyse the situation,

To save time,

We consume junk diet,

Prepared by unknown,

Served at the cost of health.

Home falls secondary;

Family at stake,

Of losing relationship values.

For Alosious, life in the lockdown meant:

To cook variety at home and serve with love,

To spend full time with family,

To listen, to share,

To spread love.

Alosious finds humanity within the bounds of her home:

locked down,

are only the gates of the house.

neither the happiness,

nor the humanity in us. (Ryan and Silvest 2020, 12-13).

The COVID-19 pandemic has left remarkable psychological imprints on humanity at large, thereby affecting relationships and gearing human life in a new direction. Fear of infection and illness, of becoming another case as those who suffer in hospitals, battling with an overpowering disease either to win or to lose, has become a directive and guideline to human relationships, narrowing the individual's circles of connections and minimizing social connectedness at all levels. Social gatherings of friends, colleagues, relatives, etc., at any time of the day and at any place that serves food and beverages seems to be a past phenomenon. Not visiting friends and parents has become an act of love. Humanity is all on guard from one another; confused feelings of love for others and fear from them surge in the psyches of individuals. In fact, the pandemic 
has stirred in humans feelings that are unfamiliar to them. Fear, as known to humans, has usually been a one-sided feeling, such as fear of death, of an evil person, or fear of a mysterious, unknown thing. Fear of another and of oneself for the same other simultaneously is, in my opinion, a new type of emotion that the pandemic has introduced to humans. Fear of infection is playing a crucial role not only in connectedness among individuals, but also in shaping the individual's psyche. If connecting with others has become a source of health threat, and if it is safer to stay within the bounds of the self, for some people the self may take precedence over others with respect to love and care. The self may become the center around which it revolves, thereby giving rise to selfishness, since the circle of connections is growing narrower, and is, ironically, becoming a source of danger. Reciprocal relationships of love and care among friends and others may consequently diminish with time if the current situation remains long. However, the consequences may take a different turn for others; deprivation of social connectedness and of the warmth of social support may result in a longing for others, in a sense of incompleteness without them. People who are socially active, for whom the company of others is of prime importance, and people who live on their own, are probably the ones who particularly suffer the bitterness of social isolation and loneliness. For them, the need for others may give way to longing for connectedness, to love and care for others, rather than to selfishness.

The current pandemic situation is a puzzling one where fear and anxiety play a crucial role in the psyches of individuals, move and guide their behavior, and most importantly, direct their relationships. A poem, entitled "Pandemicon" by Diane Seus sums up the present human situation in beautiful words: "This current situation in which what you touch can contain a little red spiked ball of death... We can kill who we touch, we can be killed by who touches us" (Quinn 2020, 137). Furthermore, "we almost have to stop living in order to save our lives" (Quinn 2020, 137). As the poem suggests, fear of contracting the virus by touching a contaminated object, or person, and fear of infecting another, impacts the individual's psyche, his/her sense of security and love for others. Fear of coming close to others, particularly loved ones, has not only left humans with feelings of loneliness and separation, but also with a marked sense of insecurity. The safest method to save our lives and the lives of others, as the 
poem suggests, is to keep away from them, to abandon everything and stay home, preferably in isolation.

Fear of infection has resulted in a stay-at-home mode of life for many people, a mode that has given rise to a sort of home attachment, and a sense of safety related to home. Home has become the only refuge from the hazards of the outside world. On the benign level, home attachment has brought families together, as afore-mentioned. Members of the same family who, in the past, found social fulfillment and entertainment with friends outside home have become closer to one another owing to the new home attachment human mode. Families who are fortunate enough to have space for all members to co-exist simultaneously now bond together rather than spend time out with friends and colleagues. Fear of losing one another is an advantage to their love as it helps accentuate it, particularly in the face of the deadly enemy outside, the pandemic, which can choose to assault any of them. However, for less fortunate people, for those who suffer strained marital relationships, strained parent-children relationships, or for those who suffer home overcrowding and poor housing conditions, their homes have become places of confinement rather than sweet homes. For them, the new mandatory "home-sweet-home" epithet, has presented multiple problems. Recent reviews of violence and domestic abuse, currently called "intimate terrorism," manifest higher records worldwide than before. "Hotlines are lighting up with abuse reports," according to New York Times (Taub 2020).

This home-based situation which the pandemic has brought on humans has geared human life in a different direction from the one it had taken for years, hence impacting all types of relationships. In many world cities, and towns with a lesser degree, dating, for instance, was an existential necessity; couples used to kiss in public transport, outdoor areas, and go out for lunch or dinner in cafes and restaurants. In the wake of the pandemic, with the social distancing measures applied in most countries, online dating has become the new dating mode. Couples are using digital communications, such as texting and video chatting; new dating applications are designed, such as "Transer," a platform for transgender dating, and others (Transer). The loss of face to face interaction among young adults may make the process of getting acquainted to a future partner become fairly impeded in the present time. Ironically, the 
pandemic is creating distances between individuals when relationships are most needed.

On a more minute scale, the COVID-19 pandemic has impacted human psychology with respect to the individual's own sense of body. Fear of infection that has affected social connectedness and bonding with others has also had a considerable share in disturbing the relation between mind and body. This is due to the fact that fear triggers feelings of distrust between the individual and parts of his/her own body, particularly hands. On a close inspection of the number of times a person washes his/her hands, or disinfects them per day- after handling objects like banknotes, supermarket receipts, shopping items, door knobs, staircase rails, a friend's handshake by mistake, or even a person's own belongings like mobiles, eyeglasses, or clothes worn outside home- it becomes obvious that there is an uneasy, stressful relationship between the individual and his/her own body and belongings. This stressful relation is further aggravated by the fact that a person should avoid touching his/her own face, or nose, if outdoors as long as his/her hands are not disinfected.

If stress has been an inevitable part of contemporary life, which is characterized by the speed of its pace and the diversity of demands it puts on the individual, the COVID-19 pandemic has elevated stress levels owing to the new pressures it holds for the individual. Those afore-mentioned feelings of discomfort are symptoms of anxiety which is triggered by stress, as aforementioned. In the words of Bourne, "It is ... stress which explains the increased incidence of anxiety disorders" (1995, introduction). Among those disorders is General Anxiety Disorders (GAD) which may develop at any age (Bourne $1995,11)$ and which is known to be chronic anxiety that has persisted for six months and is sustained by "basic fears, such as ... fear of death and disease" (1995, 11-12). From a medical perspective, the pandemic has afflicted individuals, particularly those with premorbid predispositions, with fears of contamination, disease, and death, fears which have elicited GAD within them. In fact, the pandemic may have also triggered or exacerbated Obsessive Compulsive Disorder (OCD) in individuals, since it has given rise to contamination obsessions and cleaning compulsions. 
The impact of the COVID-19 pandemic has been far reaching; it is one that has left no aspect of life untouched. Among the crucial aspects that have been profoundly affected by the pandemic is education; not only has the regular systems of education been disrupted but also relationships within those systems, particularly teacher/student relationship. As a result of the closure of universities and schools, teachers, students, and institutions had to rapidly respond to an unexpected transition from face-to-face to online education. The sudden transition was not an easy one, particularly for developing countries, due to limited access to technology and stakeholders' unfamiliarity with such a novel mode of education, problems that acted as significant stressors.

In developing countries where households have no access to digital technology and parents are illiterate, it is difficult to make online learning a successful experience. In Kenya, for instance, the incompatibility of students' socioeconomic environment with online education proved a major challenge. Although the Kenyan government responded to COVID-19 by offering the Kenya Basic Education COVID-19 Emergency Response Plan to ensure that children continued to receive instruction from home, the plan proved unworkable in the Kenyan household setting. The programs included in the plan were the Kenya Education Cloud (KEC), which hosts content for remote learning, and the Digital Literacy Program (DLP), which introduces primary school children to the use of digital technology in learning (Moyi 2020). Working out those programs turned out to be a total failure because many parents could neither provide the necessary e-learning technology, such as smartphones, laptops, Wi-Fi and hotspots, nor the support their children needed (Moyi 2020). Because school children have hardly received any education since March 2020 in Kenya, the academic year 2019-2020 was cancelled for them and declared a lost academic year by the Education Cabinet Secretary of Kenya (Moyi 2020).

For those institutions in developing countries which could financially afford access to technology, inexperience and lack of expertise in implementing it still acted as major challenges to them. A study conducted on medical education in Pakistan shows that in the new online environment of Google classrooms, videos, podcasts, virtual-reality teaching and computer simulations, 
some teachers and students were coping well while others were overwhelmed with the complexity of technology (Aziz et al. 2020, 182).

In addition to the incompatibility of online education with the socioeconomic conditions of children in developing countries and the unfamiliarity with the new educational modalities, the teacher/student interaction that typically takes place in a traditional classroom is partially lost in online education. Teaching is a dynamic process which involves teachers and learners in meaningful, collaborative efforts. The physical presence of a teacher among students is of vital importance to the learning process. Physical interactions such as eye-contact, calling a student's name, raising hands, all of which are absent in online learning, result in a vibrant, engaging learning atmosphere that encourages students, stimulates teachers, and promotes the learning process.

Learning at a distance through the internet, though has proven successful in top quality, globally recognized institutions, has its marked shortcomings. Feelings of disconnection which ensue from being away from teacher and peers and watching a teacher through a screen may easily result in lack of students' concentration, inattention and loss of interest. The problem could be further aggravated if the environments in which students are located are not agreeable, if those environments offer distractions, for instance. According to a study on distant learning, the physical separation between students and teachers creates a divide that affects learning negatively (Christiansen et al 2017, 662). Nothing could be compared to a real classroom where a teacher and students are physically present, sharing the same space, engaging in live talks and side talks, manifesting feelings for one another, making the process of learning happen.

Teacher/ student physical interaction is even more fundamental to the learning process in elementary school education; for this reason, it is preschool and elementary school children who will be most impacted by online education. For this age group, school is an equally important institution as home; if adults can learn via a screen and not be impeded by detachment from instructor and peers, young children need the physical presence of a teacher, the spirit of camaraderie, and the effect of the real classroom engagement. Those factors help them achieve better learning results. Preschool and elementary school children are at the age of developing cognitive skills, of learning the basics of 
language and math, such as recognizing letters, sounds, and colors, reading and writing letters and words, counting and adding etc., skills which demand the use of physical senses, such as seeing, touching, hearing and imitating the teacher. Acquiring those basic skills resembles a toddler's learning how to talk and walk, skills that cannot be acquired without a mother to physically assist the child during this stage. In addition, for the learning process to be successful from home, parents should get involved to assist their children, a fact that would put pressure on parents, and perhaps strain parent/child relationship.

Along with a child's cognitive skills which require face-to-interaction with a teacher, the development of his/her psychosocial skills also demand physical presence and interaction among teachers and peers, elements that are lost in internet-based learning. Scholars assert that in early childhood educational settings, students are more socially competent due to positive interactions with their teachers. According to Burchinal, Peisner-Feinberg, Pianta and Howes, both "the quality of classroom practices and the closeness of the teacher child relationships independently predicted children's language, cognitive, and social skills in preschool" $(1997,417)$. Peer interaction is equally important; it helps a child acquire coping mechanisms, such as blending in, working and cooperating with peers, making friends and fending him/herself against bullies. All those factors make the experience of school fundamental to a child's personal and social development.

Among the numerous factors, and perhaps one of the most significant, that makes school a much needed experience for a child is the relationship between teacher and child. A good teacher is not only an educator in the literal sense of the word; a good teacher is an educator of life. The impact a good teacher can have on a child may last a lifetime. A teacher may become an inspiration and a role-model to a child and the two may bond together in a relationship that is uniquely distinct from any other a child may experience in his/her life. On a side note, when we as teachers now remember our own favorite teachers, how we bonded with them, how they inspired us, as we now at times inspire our students, we realize we wouldn't have been here as academics and researchers without them. What is of interest is that as much as a child needs the love and appreciation of a teacher, a teacher reciprocally meets this with gratified love, with feelings of reward and fulfillment. It is certain that 
both teachers and students will miss out on the human aspect of one of the most fulfilling and rewarding relationships in life, hopefully only for the present time.

An example of this teacher-student relationship missed out on in the time of the COVID-19 is beautifully expressed by an elementary school teacher, Rachel Pappas, in Texas who writes the following lines in prose: "It has been so hard... I am not designed to sit at a desk all day and talk to a camera." In poetry, she writes:

Today, my classroom didn't lose a pencil,

I didn't throw away any glue.

I didn't help a child,

Who didn't know what to do.

Today, my crayons went unused,

And the scissors stayed nice and sharp,

But everywhere else,

Things seemed to be falling apart.

Today, I didn't hug my students

Or tell them each I loved them. I didn't teach reading, writing,

Or how to decompose 10

How many pencils I would give,

Just to have my students back. (Melissa 2020).

One major issue the COVID-19 has impacted, in fact has stimulated to reach its full potential to meet the challenges the pandemic has presented, is technology. Had it not been for technology, modern society with its work sectors, businesses, education, medical services, social network etc. would have fallen apart with the outbreak of the pandemic. Modern technologies have accommodated for the loss of physical presence mandated everywhere by the social distancing measures the pandemic has made necessary to impose. 
The pandemic has acted as "an accelerator for digital change" (Tags 2020) that was already undercurrent in many aspects of life, yet was not fully implemented. Technology had already offered humans colossal lifestyle changes over the past decades when it presented them with electronic communication, such as emailing, online booking and shopping, as well as social networking with loved ones on the other side of the globe on applications such as Facetime, skype, WhatsApp and others. Those products of luxury and convenience have not only eliminated the barriers of time and space, but also the need for physical presence. However, those services that technology had rendered man in the past are not all the cards it has on the table. The outbreak of the pandemic has pushed technology, as it were, to play all its cards, impacting relationships in novel ways.

The global, unprecedented experience of work from home in the pandemic era is one of the achievements and successes of technology which has saved institutions, businesses, employers and employees worldwide from going bankrupt. Tasks in work fields that require physical presence and co-working with colleagues side by side are accomplished through technology in several firms and businesses via video-conferencing, instant messaging, file- sending and sharing platforms (Tags 2020). At a more advanced level, employers and employees are able to work together in some companies while physically miles and miles away, by sharing the same virtual space in real time through VR (Virtual Reality) and AR (Augmented Reality)-“an environment which allows each participant to interact with 3D elements and find themselves within absolutely realistic simulations" (Tags 2020). The COVID-19 pandemic has given rise to a new phenomenon wherein people will rely on tools like VR and AR for working, shopping (Joshi 2020) and consulting doctors through telemedicine.

Technology has also played a significant role in social life during the pandemic, and may continue to do so after the pandemic. People are becoming creative with virtual reality, substituting it for physical presence in meetings and social events, such as weddings and birthdays. Other technological programs, already known on a large scale, for e.g. zoom, are currently resorted to for the afore-mentioned purposes. Instead of the cancellation of wedding ceremonies, as was the case in most countries during the lockdown, zoom weddings are now 
taking place in many parts of the world, thus bringing the party home instead of going to the party.

In India, a country known for its lavish weddings with cocktail partying, and elaborate feasting, a country where parents save money throughout their lives for this special day when a son or a daughter gets married, zoom weddings are taking place in the present time. Instead of the bride and groom walking the aisle together, a humorous story goes that Dang and Narang, each in his/her parents' home in cities far away from each other, and the priest yet in a third city, all appear on the screen and hundreds of guests logged on from their homes to attend the wedding (Rai 2020).

It seems that the pandemic has directed certain aspects of human life the ways countries and governments wished them to be- quite a coincidence. The Indian government had been trying for years to limit the rocketing extravagances of weddings, the expenses of hotel bookings, caterers, food and all the lavish paraphernalia that goes with weddings (Rai 2020). The pandemic has surprisingly done it all.

The pandemic has impacted human psychology and relationships in ways that have created distances between individuals. It has not only made necessary social distancing among people, but has also brought in its wake the concept of elimination of their physical presence. If work, education, dating, marriage and social relations can be done remotely, the need for being physically present seems to be on its way to becoming an obsolete concept.

The pandemic has brought new trends in its wake. The needlessness for physical presence has urged people to abandon cities, with their high living costs and polluted air, and to live in the suburbs. Many world cities that used to glow with life and with visitors from every corner of the world, such as London, New York, and San Francisco are now abandoned by many of their residents (Stevens 2020). The needlessness for physical presence will also impact relationships; distances may create mental and psychological distances between individuals. I think all we have to do at present is to wait and see which turns and bends human life will take after the pandemic. 


\section{Conclusion}

The COVID-19 pandemic has left true marks on human life, primarily because it has touched deeply on the human psyche and on human relationships. Along with all the minute details of the pandemic-related change that has recently occurred in human life, the fact remains that the pandemic has left people with a deep sense of loneliness and insecurity because it has disrupted habitual thought within them. The overturn of the shape of life on earth over such a short period of time has shaken the normalcy to which humans have long been accustomed to. In a six-month span, people have witnessed a dramatic change in all aspects of life, and, more importantly, have experienced loss in its deepest meanings. Loss of humans, money, jobs, and financial and emotional security on a global level have impoverished the mental and psychological health of individuals, yet have imbued life with new meanings. The wide-scale experience of loss which humans have gone through over the past months has brought new insights into human life on this planet. Our current togetherness in a new present-one in which we have survived a colossal wave, as it were, however uncertain we are of surviving another, of who will survive or get toppled by other consecutive waves, of who will remain on board the ship, not forever though but temporarily - should drive us to hold on to one another, to be kind to our fellow brothers, to give them, not a hand but, all our hands in order for the human journey to be a happy one, and in order for them not to fall off the ship prematurely.

\section{Works Cited}

Aziz, Anbreen, Sidra Aamer, Asma Munir Khan, Mashaal Sabqat, Marium Sohail, and Farzana Majeed. 2020. "A Bumpy Road to Online Teaching: Impact of COVID-19 on Medical Education." Annals of King Edward Medical University 26, special issue (July): 181-186. https://www.annalskemu.org/journal/index.php/annals/article/view/3635

Bhuiyan, AKM Israfil, Najmuj Sakib, Amir H. Pakpour, Mark D. Griffiths, and Mohammed A. Mamun. 2020. "COVID-19-Related Suicides in Bangladesh Due to Lockdown and Economic Factors: Case Study 
Evidence." International Journal of Mental Health and Addiction (May). https://doi.org/10.1007/s11469-020-00307-y

Bourne, Edmund J. 1995. The Anxiety and Phobia Workbook. New York: New Harbinger Publications.

Burchinal, Margaret R., Ellen Peisner-Feinberg, Robert Pianta, and Carollee Howes. 2002. "Development of Academic Skills from Preschool Through Second Grade: Family and Classroom Predictors of Developmental Trajectories." Journal of School Psychology 40 (5): 415 - 436. https://doi.org/10.1016/S0022-4405(02)00107-3

Christiansen, Michael A., Louis Nadelson, Lianna Etchberger, Marilyn Cuch, Trish A. Kingsford, and Leslie O. Woodward. "Flipped Learning in Synchronously-Delivered, Geographically-Dispersed General Chemistry Classrooms." The American Chemical Society and Division of Chemical Education 94, no. 5 (March): 662-667. https://doi.org/10.1021/acs.jchemed.6b00763

Cornwell, Benjamin and Edward O. Laumann. 2015. "The Health Benefits of Network Growth: New Evidence from a National Survey of Older Adults." Social Science \& Medicine 125 (January): 94-106. https://doi.org/10.1016/j.socscimed.2013.09.011

Correa, Melissa. 2020. "Katy ISD elementary teacher writes beautiful poem reflecting new normal for educators." Khou. Last modified May 4, 2020. khou.com/article/news/health/coronavirus/katy-isd-teacher-poem-aboutmissing-kids-and-working-from-home/285-e8b90235-ac6f-4ee2-a28c4f5f8ba72577

Donnan, Shawn, Deaux Joe, Pickert Reade, and Keith Naughton. 2020. "BlueCollar America Braces for Another Devastating Recession." Bloomberg, April 3, 2020. https://www.bloomberg.com/news/articles/2020-0402/blue-collar-america-braces-for-another-devastating-recession 
EURACTIV. "German Minister commits suicide after "virus crisis worries." March 30, 2020.

https://www.euractiv.com/section/economy-jobs/news/german-ministercommits-suicide-after-virus-crisis-worries/

Griffiths, Mark D. and Mohammed A. Mamun. 2020. "COVID-19 Suicidal Behavior Among Couples and Suicide Pacts: Case Study Evidence From Press Reports." Psychiatry Research 289 (July): 113105. https://doi.org/10.1016/j.psychres.2020.113105

Hawkley, Louise C., and John P. Capitanio. 2015. "Perceived Social Isolation, Evolutionary Fitness and Health Outcomes: A Lifespan Approach." Philosophical Transactions of the Royal Society B 370, no. 1669 (May): 1-12. https://doi.org/10.1098/rstb.2014.0114

Hussey, Andrew. 2020. "Paris is an Open Prison." New Statesman, April 1, 2020. https://www.newstatesman.com/world/europe/2020/04/paris-openprison

Indolfi, Ciro, and Carmen Spaccarotella. 2020. "The Outbreak of COVID-19 in Italy: Fighting the Pandemic." Journals of the American College of $\begin{array}{llllll}\text { Cardiology } 2, & \text { no. } & 9 & \text { (July): } & 1414-1418 .\end{array}$ https://doi.org/10.1016/j.jaccas.2020.03.012

Joshi, Nikhil. 2020. "Will Covid-19 change the fate of Virtual Reality and Augmented Reality." The Economic Times, April 16, 2020. https://cio.economictimes.indiatimes.com/news/next-gentechnologies/will-covid-19-change-the-fate-of-virtual-reality-andaugmented-reality/75177197

Kilbourne, Edwin D. 1977. "Influenza Pandemics in Perspective." Journal of the American Medical Association 237, no. 12 (March): 1225-1228. https://doi.org/10.1001/jama.1977.03270390041023

Mamun, Mohammed A. and Irfan Ullah. 2020. "COVID-19 Suicides in Pakistan, Dying off not COVID-19 Fear but Poverty? - The Forthcoming 
Economic Challenges for a Developing Country." Brain Behavior and Immunity 87 (July):163-166. https://doi.org/10.1016/j.bbi.2020.05.028

Marroquin, Brett, Vera Vine, and Reed Morgan. 2020. "Mental Health during the COVID-19 Pandemic: Effects of Stay-At-Home Policies, Social Distancing Behavior, and Social Resources." Psychiatry Research, 293 (November): 113419. https://doi.org/10.1016/j.psychres.2020.113419.

Moyi, Peter. "Out of Classroom Learning: A Brief Look at Kenya's COVID-19 Education Response Plan." Journal of the Commonwealth Council for Educational Administration \& Management 48 (3): 59-65. EBSCOhost.

PR Newswire. 2020. "Transer, a New Transgender Dating Application with Text-Based Message Features, Debuts Worldwide During the Covid-19 Pandemic." May 28, 2020. https://www.prnewswire.com/newsreleases/transer-a-new-transgender-dating-application-with-text-basedmessage-features-debuts-worldwide-during-the-covid-19-pandemic301066549.html.

Rai, Saritha. 2020. "India's Once Lavish Weddings Are Now Taking Place on Zoom.” Bloomberg, $\quad$ April 23, 2020. https://www.bloomberg.com/news/articles/2020-04-23/india-s-oncelavish-weddings-are-now-taking-place-on-zoom

Semuels, Alana. 2020. “After the Meltdown.” Time Magazine, March 30, 2020, 38-39.

Siddiqui, Kalim. 2020. "The Impact of COVID-19 on the Global economy." World Financial Review, June 24, 2020. https://worldfinancialreview.com/the-impact-of-covid-19-on-the-globaleconomy/

Silvest, R.S. Regin and John Charles Ryan. 2020. COVID-19 Pandemic Poems. Tamil Nadu: Cape Comorin Publisher. 
Stevens, Shaun. 2020. "City of Fear? Fear of the city? Urban life and COVID19." BNP Paribas, October 10, 2020. https://investors-corner.bnpparibasam.com/economics/city-of-fear-fear-of-the-city-urban-life-and-covid-19/

Tags, David. 2020. "HOW COVID-19 IS AFFECTING THE DEVELOPMENT OF VIRTUAL AND AUGMENTED REALITY." Vection.n.d. Accessed December 15, 2020. https://www.vection.com.au/news/post/how-covid19-affecting-development-virtual-and-augmented-reality doi:
10.1016/j.bbi.2020.04.062 DOI:
10.1016/j.bbi.2020.05.028 DOI:
10.1016/j.bbi.2020.05.028doi: 10.1159/000507639

Taub, Amanda. 2020. "A New COVID-19 Crisis: Domestic Abuse Rises Worldwide." The New York Times, April 6, 2020. https://www.nytimes.com/2020/04/06/world/coronavirus-domesticviolence.html.

Taylor, Steven. 2019. The Psychology of Pandemics: Preparing for the Next Global Outbreak of Infectious Disease. Newcastle upon Tyne: Cambridge Scholars Publishing.

The World Bank. 2020. "World Bank's Response to COVID-19 (Coronavirus) in Africa." October 2020. https://www.worldbank.org/en/news/factsheet/2020/06/02/world-banksresponse-to-covid-19-coronavirus-in-africa

United Nations Development Programme UNDP. 2020. "COVID-19: Looming Crisis in Developing Countries Threatens to Devastate Economies and Ramp Up Inequality.” March 30, 2020. https://www.undp.org/content/undp/en/home/newscentre/news/2020/CO VID19_

Crisis_in_developing_countries_threatens_devastate_economies.html

Usuelli, Michele. 2020. "The Lombardy region of Italy launches its first Investigative COVID-19 commission." The Lancet 396, no. 10262 (November): E86-E87. https://doi.org/10.1016/S0140-6736(20)32154-1

Vection. n.d. "How Covid-19 is Affecting the Development of Virtual and Augmented Reality.” Accessed December 15, 2020. 
https://www.vection.com.au/news/post/how-covid-19-affectingdevelopment-virtual-and-augmented-reality

Weber, Michael, Amparo Palacios-Lopez, and Ivette Maria Contreras-González. 2020. "Labor market impacts of COVID-19 in four African countries." The World Bank. November 18, 2020. https://blogs.worldbank.org/opendata/labor-market-impacts-covid-19four-african-countries

Jacofsky, Mathew, Melanie Santos, Sony Khemlani-Patel, Fugen Neziroglu, C.E. Zupanick, and Mark Dombeck. "Biological explanations of Anxiety, part 11" https://www.gracepointwellness.org/1-anxietydisorders/article/38471-biological-explanations-of-anxiety-part-ii 
العالم يترنح من جائحة عالمية: كوفيل_و 19 وانعكاساته الاجتماعية والنفسية

\author{
مايسة عبد العال ابراهيم

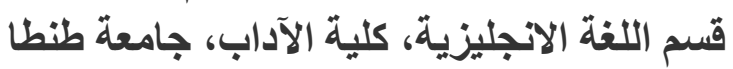 \\ maysa.ibrahim@gmail.com
}

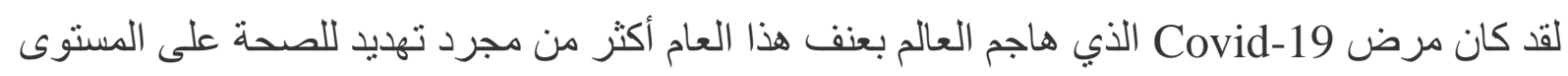

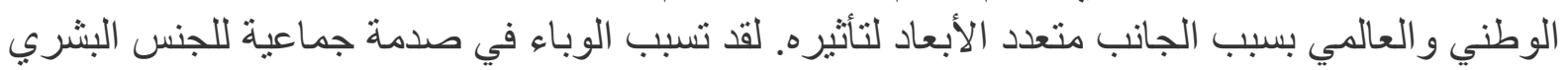

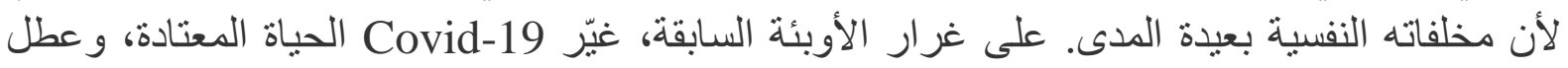

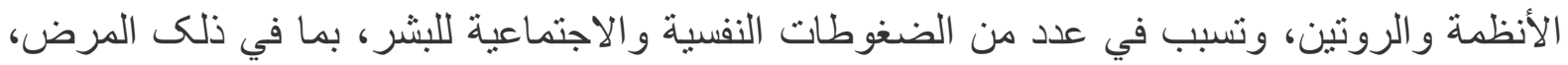

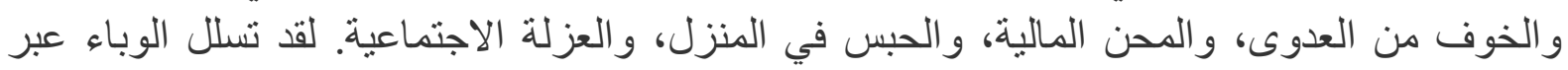

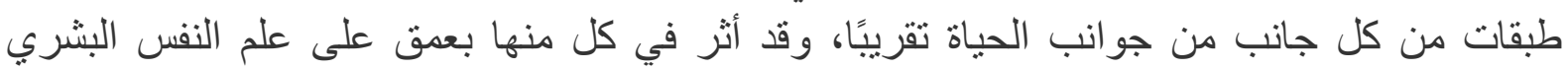

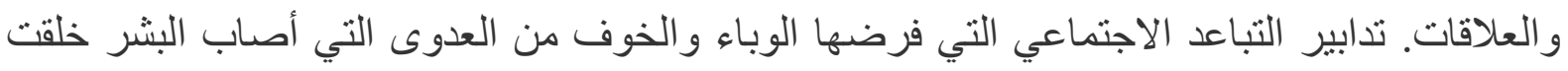

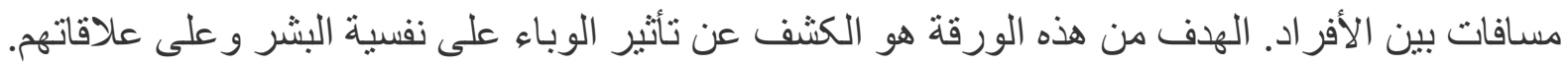

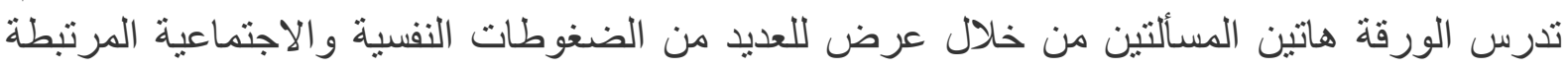

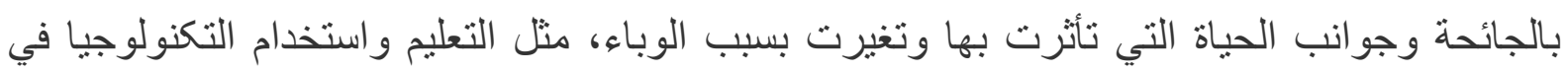

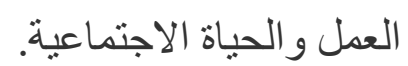

الكلمات المفتاحية: كوفيد ـ9 (، إغلاق، ركود اقتصادي، قلق، اكتئاب 